\title{
ESTADO DE EXCEÇÃO E DEMOCRACIA FRAGMENTADA NO BRASIL: UM BREVE ENSAIO A RESPEITO DO “GOLPEACHMENT” DE 2016
}

Wellington Fontes Menezes*

Resumo: Neste presente trabalho, busca-se um estudo preliminar das condições impostas por uma nova dinâmica em que a democracia foi subjugada e percebe-se a consolidação de domínio de um estado de exceção. O retorno das lições de Carl Schmitt e as considerações mais contemporâneas de Giorgio Agamben contribuem para o entendimento e formulação de um novo paradigma de atuação que não é inscrita na lei, mas está atuante em uma zona intermediária entre a democracia e o absolutismo. Um novo momento da vida nacional brasileira se inicia com a consolidação de mais um golpe de estado após um intenso processo de articulação política de grupos de interesses para a deposição da presidenta Dilma Rousseff em agosto de 2016, por sinal, golpe este travestido com um pretenso ornamento jurídico com base parlamentar por via de um "impeachment", que poderá ser mais bem traduzido pela expressão "golpeachment". A construção deste processo tem profundas raízes na fragmentada democracia e ranço autoritário das classes dominantes brasileiras.

Palavras-chave: Carl Schmitt; Golpe de estado; Lava-Jato; Poder judiciário; Política brasileira.

Abstract: In this work, a preliminary study of the conditions imposed by a new dynamics where democracy has been subjugated and the domination consolidation of a state of exception is perceived. The return of the lessons of Carl Schmitt and the more contemporary considerations of Giorgio Agamben contribute to the understanding and formulation of a new paradigm of performance that is not inscribed in the law, but is acting in an intermediate zone between the democracy and the absolutism. A new moment in Brazilian national life begins with the consolidation of another coup d'état after an intense process of political articulation of interest groups for the deposition of President Dilma Rousseff in August 2016. By the way, this transvestite coup with a pretender with a parliamentary basis by means of an impeachment, which may be better translated by the expression "golpeachment". The

*Doutorando do Programa de Pós-graduação em Sociologia e Direito da Universidade Federal Fluminense (UFF). Mestre em Ciências Sociais pela Universidade Estadual Paulista (UNESP). Licenciado em Ciências Sociais pela Universidade Cidade de São Paulo (UNICID). Bacharel e Licenciado em Física pela Universidade de São Paulo (USP). 
construction of this process has deep roots in the fragmented democracy and authoritarian rancor of the Brazilian ruling classes.

Key-words: Carl Schmitt; Coup d'etat; Lava-Jato; Judicial power; Brazilian politics.

\title{
1. Introdução
}

\author{
"Queimar era um prazer". \\ (Ray Bradbury, "Fahrenheit 451", 1953)
}

Crise, ruptura, descontinuidade, golpe, fragmentação... Estas são palavras muito utilizadas para descrever os processos políticos envoltos na sociedade brasileira desde 1889, ocasionando a queda da monarquia e a ocupação por uma junta militar que inaugurou a "república" por via de um golpe militar. Este fato histórico foi marcado por intensas disputas pelo poder e dominação entre as classes que buscavam a hegemonia no controle do país, cujas mudanças econômicas e interesses particularizados estavam no cerne de todo este processo.

Desde o deslocamento dos centros do poder do Rio de Janeiro para Brasília, nos anos 1960, as mudanças estruturais da economia brasileira, no entanto, sem ocorrerem mudanças ou rupturas do poder dos grupos econômicos para as classes trabalhadoras, permitiram ao país assistir a uma série de instabilidades políticas com poucos ares democráticos ao longo do processo republicano. Por sinal, se somarmos o número de anos em que a democracia política esteve presente no cenário nacional, não passará de um terço de todo o período republicano até agora constituído e vivenciado na sociedade brasileira. Merece destaque emblemático um registro de um cronista de época, Aristide Lobo, em 1889, a respeito da nascente república brasileira alheia do conhecimento e interesse das classes populares, que viam, absortos, o seu surgimento:

$\mathrm{O}$ povo assistiu àquilo bestializado, atônito, surpreso, sem conhecer o que significava. Muitos acreditavam sinceramente estar vendo uma parada. Era um fenômeno digno de ver-se. O entusiasmo veio depois, veio mesmo lentamente, quebrando o enleio dos espíritos. Pude ver a sangue frio tudo aquilo. Mas voltemos ao fato da ação rude ou do papel governamental: estamos em presença de um esboço rude, incompleto, completamente amorfo. (CARONE, 1976, p. 377)

Em um novo estágio de desenvolvimento da vida brasileira, a situação política, social e jurídica poderá ser sentida com uma traumática desorganização das condições de vida da sociedade. Podemos encontrar elementos intrínsecos na dinâmica sociopolítica brasileira: o 
encaminhamento de uma democracia assimétrica, fragmentada, com grandes desníveis sociais, modernidade excludente, sistema judiciário com seletividade penal e monopólio das comunicações com forte aparato ideológico e partidarizado. Ademais, sobre todo este sistema, temos ainda uma brutal e injusta distribuição de renda atrelada à ideologia de mercado e à meritocracia. Pode-se ressaltar que apesar do quadro ainda ser alarmante, nos últimos anos, ocorreu uma lenta redução da pobreza.

No atual plano político nacional, consumando o golpe de Estado travestido de um “impeachment”, em 2016, o segundo em pouco mais de cinquenta anos, o Brasil entrou em uma nova era de sombras e incertezas. A natureza deste último é peculiar, uma vez que se travestiu de "normalidade jurídica" de um "impeachment", o qual se pode traduzir um neologismo oportuno: o "golpeachment". No dia 31 de agosto de 2016, por 61 votos favoráveis e 20 contra, o Senado Federal aprovou a destituição da presidenta Dilma Rousseff sob a alegação de "impeachment", de um julgamento em que não houve nenhuma comprovação cabal de "crime de responsabilidade", fato esse que os mesmos senadores que julgaram Dilma, destituindo-a da Presidência, permitiram que seus direitos políticos ficassem preservados. Agora, mais uma vez na história do Brasil, um vice-presidente, de forma indireta pela via do "impeachment", é entronado na principal cadeira do poder nacional, sendo ele, o atual conspirador maior da República: Michel Temer.

O presente trabalho tem como proposta iniciar um estudo a respeito das implicações de um estado de exceção, após mais um novo golpe de Estado no Brasil protagonizado pelo Poder Legislativo com anuência do Poder Judiciário, em detrimento do arcabouço normativo constitucional e descarte do estado democrático de direito.

\section{O estado de exceção como práxis das democracias contemporâneas}

$\mathrm{O}$ atual ordenamento jurídico envolto nas democracias contemporâneas merece atenção de todos aqueles que primam pelo respeito à dignidade humana frente às formas manifestadas inscritas ou subjetivas de barbárie. Neste vasto campo, o presente trabalho pretende estabelecer algumas considerações conceituais sobre o estado de exceção como paradigma e práxis das democracias ocidentais ou ocidentalizadas a partir do atual contexto do estado brasileiro.

Remetendo à ideia de construção dos Estados Modernos, ressaltam-se elementos que arregimentaram a consolidação dos seus processos políticos e sociais. A constituição dos 
estados modernos mescla uma série de fatores e construções de uma amálgama de predicados ao longo da história:

\begin{abstract}
A modernidade democrática contemporânea associa, de uma maneira sem exemplos no passado, valores pré-modernos, modernos e pós-modernos. Pré-modernos: ética do sacrifício e sofrimento passivo, ordem social estática e sofrimento passivo, ordem social estática como por intervenção divina. Modernos: o individualismo possessivo e os valores de mudanças e progresso. Pós-modernos: o Estado não garante o bem comum, a proteção dos direitos sociais e civis é considerada, melhor dizendo, um estorvo (MATOS, 2003, p. 48).
\end{abstract}

A princípio, se faz necessária a distinção entre soberania e estado de exceção, que foi estabelecida inicialmente por Carl Schmitt em 1922, na obra "Teologia Política", que define a respeito do soberano como "aquele que decide sobre o estado de exceção" (SCHMITT apud AGAMBEN, 2004, p. 11). Em seu ensaio a respeito do estado de exceção, Giorgio Agamben delimita algumas condições que dão suporte para a compreensão do estado de exceção e sua instauração dentro de um Estado supostamente democrático, mais particularmente, pela “força de lei” por parte do soberano ao modo schmittiano:

O estado de exceção não é uma ditadura (constitucional ou inconstitucional, comissária ou soberana), mas um espaço vazio de direito, uma zona de anomia em que todas as determinações jurídicas - e, antes de tudo, a própria distinção entre público e privado - estão desativadas. Portanto, são falsas todas aquelas doutrinas que tentam vincular diretamente o estado de exceção ao direito, o que se dá com a teoria da necessidade como fonte jurídica originária, e com a que vê no estado de exceção o exercício de um direito do Estado à própria defesa ou a restauração de um originário estado pleromático do direito (os "plenos poderes"). (AGAMBEN, 2004, p. 78-79)

A “zona de anomia" citada por Agamben (2004), ou seja, um espaço vazio do Direito, introduz aos infortúnios passíveis que vitalizam os rizomas das transgressões do estado democrático de direito. Logo, a democracia com molde liberal seria a força-motriz que medeia a natureza dos homens, em potencial, a sociedade constituída pelos "cidadãos", criação basilar do Ocidente moderno, onde os ordenamentos jurídicos dariam condições igualitárias de direitos ao conjunto dos "cidadãos" frente às imposições de um Estado severamente coercitivo e com o pressuposto real do monopólio da violência.

Todavia, o instrumento do estado de exceção não é nenhuma novidade frente às políticas dos Estados-nacionais. A teoria do estado de exceção foi inaugurada em 1921 por Carl Schmitt em um estudo sobre a ditadura, e que se tratava inicialmente como uma “ditadura constitucional” (AGAMBEN, 2004, p. 17). Sobre a importância de percepção do estado de exceção no período envolvendo as duas grandes guerras mundiais, temos que: 
A Primeira Guerra Mundial - e os anos seguintes - aparece, nessa perspectiva, como o laboratório em que se experimentaram e se aperfeiçoaram os mecanismos e dispositivos funcionais do estado de exceção como paradigma de governo. Uma das características essenciais do estado de exceção - a abolição provisória da distinção entre poder legislativo, executivo e judiciário - mostra, aqui, sua tendência a transformar-se em prática duradoura de governo. (AGAMBEN, 2004, p. 19)

Os abusos do exercício sistemático e regular do estado de exceção, segundo Agamben (2004, p. 19), "levariam necessariamente à liquidação da democracia". Neste sentido, a democracia estaria em "suspensão" na vigência do estado de exceção e um novo regime se imporia, levando a um estado de permanente coação dos seus cidadãos. Agamben (2004, p. 13) define esse estado como "guerra civil mundial":

[...] o estado de exceção tende cada vez mais se apresentar o paradigma de governo dominante na política contemporânea. Esse deslocamento de uma medida provisória e excepcional para uma técnica de governo ameaça transformar radicalmente - e, de fato, já transformou de modo muito perceptível - a estrutura e o sentido da distinção tradicional entre os diversos tipos de constituição. O estado de exceção apresentase, nessa perspectiva, como um patamar de indeterminação entre democracia e absolutismo. (AGAMBEN, 2004, p. 13)

As democracias modernas ocidentais foram cooptadas pelas grandes corporações capitalistas. Os Estados, cujos governos são cada vez mais dependentes de "democracias eleitorais" com grande aporte de capital privado para eleger seus governantes (na verdade, a luta é para quem é o "melhor gestor" da "coisa pública", que se confunde com a "coisa privada"), não mais trabalham para o usufruto dos seus cidadãos, mas, ao contrário, criam-se formas autoritárias de coerção dos mesmos, para manter a lógica de dominação capitalista, pulverizando a pluralidade e atomizando-a na retórica das diferenças culturalistas pósmodernas sob os auspícios da barbárie, uma vez que:

O fetichismo da economia converte a política em bode expiatório: a democracia substituída por lobbies e o enfraquecimento da dimensão simbólica da Lei resultam em indiferença política; o fim da democracia como esperança dá-se sob os auspícios do capitalismo tardio. Este substitui a democracia da pluralidade por aquela da "diferença" $[. .$.$] fratura-se a sociedade pela via do gueto e da tribo [...], construindo$ sociedades etnicamente homogêneas e, como se sabe, a pureza de sangue, de espírito ou de conhecimento está na origem de todas as barbáries. (MATOS, 2003, p. 48)

Sobre sua pertinência na História, o estado de exceção esteve vigente em diversas democracias (ou países tido como outrora “democráticos”). O paradigma basilar que se pode encontrar no período que abrangeu o final da Alemanha, durante a República de Weimar e 
durante todo o regime Nacional-socialista, é o estado nazista, liderado por Adolf Hitler. Logo que subiu ao poder, Hitler, com auxílio das suas tropas de assalto, a SA (Sturmabteilung), em 27 de fevereiro de 1933, forja um incêndio no palácio presidencial do Reichstag. A responsabilidade pelo atentado caiu sobre as costas dos comunistas, adversários do grupo nazista de Hitler. A orquestração do episódio teve a comoção esperada por Hitler. No dia seguinte, Hitler persuadiu o presidente alemão Paul Von Hindenburg a assinar o chamado "Decreto para a proteção do povo e do Estado" e que tinha como efeito a suspensão dos artigos da Constituição de Weimar no que se referia às liberdades individuais e civis (PRINTCHARD, 1976) ${ }^{1}$. A esse respeito, o estado de exceção se instaurava na Alemanha da ascensão nazista, perdurou até o seu fim, em 1945, e mostrou a face mais intensa e devastadora do totalitarismo moderno:

O decreto nunca foi revogado, de modo que todo o Terceiro Reich pode ser considerado, do ponto de vista jurídico, como um estado de exceção que durou 12 anos. O totalitarismo moderno pode ser definido, nesse sentido, como a instauração, por meio do estado de exceção, de uma guerra civil legal que permite a eliminação física não só dos adversários políticos, mas também de categorias inteiras de cidadãos que, por qualquer razão, pareçam não integráveis ao sistema político. (AGAMBEN, 2004, p.13)

Sendo assim, é pertinente observar a inserção de um novo paradigma político, imposto sob a forma de uma construção não-inscrita de um ordenamento jurídico ao sabor do soberano ao estilo schmittiano, alicerçando práxis de dominação de âmbito a todos os Estados ditos democráticos:

Desde então, a criação voluntária de um estado de emergência permanente (ainda que, eventualmente, não declarado no sentido técnico) tornou-se uma das práticas essenciais dos Estados contemporâneos, inclusive dos chamados democráticos. (AGAMBEN, 2004, p. 13)

É preciso ainda fazer uma distinção entre estado de exceção e estado de sítio, de defesa ou medida jurídica similar excepcional que é amparada em lei. Por sinal, este último está inscrito na Constituição Federal Brasileira (BRASIL, 1998), nos artigos 137 a 139, como elemento de um ordenamento jurídico. Conforme aponta SERRANO (2016, p. 33), a respeito do estado de exceção: "trata-se de algo fora do direito, em que este é suspenso, prevalecendo

\footnotetext{
${ }^{1} \mathrm{O}$ episódio do incêndio do Reichstag ainda permanece controverso. Historiadores como Martin Kitchen defendem que foi realizado por um ato unilateral de um militante comunista e que teve relevâncias graças a uma série de "coincidências" danosas que permitiram a Hitler explorar os fatos para seus planos pessoais de governo e impor seu ideário de medo e xenofobia social (KITCHEN, 2013).
} 
a decisão soberana". É importante atentar-se para as circunstâncias do estado de exceção que são impostas pelo soberano e implicam o seu entendimento:

[...] a escolha da expressão "estado de exceção" implica uma tomada de posição quanto à natureza do fenômeno que se propõe a estudar e quanto à lógica mais adequada a sua compreensão. Se exprimem uma relação com o estado de guerra que foi historicamente decisiva e ainda está presente, as noções de "estado de sítio" e de "lei marcial" se revelam, entretanto, inadequadas para definir a estrutura própria do fenômeno e necessitam, por isto, dos qualificativos "político" ou "fictício", também um tanto equívocos. $\mathrm{O}$ estado de exceção não é um direito especial (como o direito de guerra), mas, quando suspensão da própria ordem jurídica, define seu patamar ou seu conceito limite. (AGAMBEN, 2004, p. 15)

Ressalta-se ainda o papel do soberano schmittiano, ou seja, aquele que induz por própria vontade a imposição do estado de exceção. A consolidação ou execução do estado de exceção visa proteger os interesses subjacentes ao Estado e não seus cidadãos, ou seja, na situação limite, estabelecer a prerrogativa de proteção do Estado frente aos seus próprios cidadãos! Conforme salienta Agamben (2004, p. 30), a instauração por via de um estado de exceção se configuraria uma "democracia protegida" como regra e não mais como uma excepcionalidade.

A instabilidade e a fragilidade das democracias contemporâneas, com forte rejeição e desconfiança dos cidadãos, com baixa participação ativa dos mesmos, além da evocação de uma "desnaturalização" da política do meio social e banalização do sentido de se fazer política na sociedade (em geral, confundida com as disputas fratricidas entre partidos políticos), são elementos que ajudam a diluir a organização política da ação da democracia participativa em um Estado e aliando-se ainda a uma grande porosidade e aglutinação indevida entre os poderes da República:

Isto significa que o princípio democrático da divisão de poderes hoje está caduco e que o poder executivo absorveu de fato, ao menos em parte, o poder legislativo. $\mathrm{O}$ Parlamento não é mais o órgão soberano a quem compete o poder exclusivo de obrigar os cidadãos pela lei: ele se limita a ratificar os decretos emanados do poder executivo. Em sentido técnico, a República não é mais parlamentar e, sim, governamental. E é significativo que semelhante transformação da ordem constitucional, que hoje ocorre em graus diversos em todas as democracias ocidentais, apesar de bem conhecida pelos juristas e pelos políticos, permaneça totalmente despercebida por parte dos cidadãos. Exatamente no momento em que gostaria de dar lições de democracia e culturas e as tradições diferentes, a cultura política do Ocidente não se dá conta de haver perdido por inteiro os princípios que a fundam. (AGAMBEN, 2004, p. 32-33) 
Sobre esta mutação do papel do judiciário, a amálgama entre os poderes e os protagonismos de alguns de seus operadores da lei fora da norma (aqui aparece outra dimensão dos abusos do estado de exceção), temos que:

\begin{abstract}
A perversão democrática consubstanciada numa usurpação do poder representativo do parlamento, diretamente eleito pelo Povo, de ter um juiz além da lei, assumindose como representante dos juízos de censura da comunidade e do sentimento comum de justiça, sem ser eleito para tal, sem ter o prestígio inerente à sua competência jurídica (auctorias), com comportamentos de vedeta e exibição pública da função de judicatura - nada tem a ver com a jurídico. Esta situação de juízes autoconsiderados representantes da comunidade com tiques populistas e sentenças assentes nas idiossincrasias corporativas de grupos e na ideologia de quem julga, subvertendo uma legitimidade indireta via nomeação pelo titulares de cargos políticos resultantes de eleições subverte o Estado de Direito através de uma jurisprudência sem jurídico e sem Prudentia por juízes sem carreira, sem regra, apesar do Povo. O ativismo judiciário seria, então, a expressão do autoritarismo estatal pela ação do juiz da legalidade convertido no juiz de Direito por apelo à Constituição. (VERA-CRUZ PINTO, 2016, p. 10, grifos do autor)
\end{abstract}

Conforme ressalta Matos (2003, p. 49), “onde não há política governam a violência e o terror". O estado de exceção é a negação da liberdade e da democracia dentro de um Estado. Seus cidadãos ficam reféns de um estado onde o soberano emprega leis como um arauto divino, tal como Carl Schmitt comparava o estado de exceção na política ao milagre na teologia. O conflituoso trade off entre liberdade e segurança é cada vez mais voltado para o segundo pressuposto vital com a falência da Política como mediação entre os cidadãos, prossegue, assim, Matos (2003, p. 49): “o descrédito no parlamento, nas instituições políticas de representação social, na punição de sua violação, em sua aplicabilidade faz com que, hobbesianamente, troque-se liberdade por segurança".

\title{
3. O entrelaçamento de mais um golpe de estado no Brasil e o seu desenrolar na sociedade brasileira
}

Finalizou-se com um golpe de estado parlamentar um longo processo de desgaste do Partido dos Trabalhadores (PT) na esfera federal com treze anos no poder e que foi se arrastando com mais ímpeto desde os protestos no inverno de 2013. Naquela ocasião, uma “onda conservadora" capturada por um forte e sistemático discurso ideológico midiático transformou simples protestos contra a alta nos preços de tarifas de transporte público 
paulistano em uma onda irracional de ódios canalizada em uma torrente de insatisfações sem maior densidade de realismo político contra o governo Dilma Rousseff por todo o país ${ }^{2}$.

Uma pergunta que merece um maior desdobramento reflexivo é: qual o significado do golpe? Em primeiro lugar é preciso compreender o colapso do que foi a "Nova República", período que sucedeu o processo de redemocratização do Brasil após o golpe de 1964, inaugurado com o advento da transição para a abertura democrática em 1985, com a eleição indireta de Tancredo Neves e, com sua morte antes de tomar posse, sendo sucedido por seu vice, José Sarney (1985 a 1990). A primeira eleição direta para presidente após o golpe de 1964 deu início ao conturbado período de Fernando Collor de Mello (1990-1992) que foi interrompido por um "impeachment" e sucedido pelo mandato de seu vice, Itamar Franco (1992-1995). Posteriormente, a presidência foi passada para as mãos de Fernando Henrique Cardoso (1995-2003), Luís Inácio Lula da Silva (2003-2011) e, por fim, a gestão de Dilma Rousseff (2011-2016), por sinal, todos eleitos democraticamente pela via eleitoral.

Agora, mais uma interrupção brusca da democracia brasileira foi marcada pelo golpe parlamentar de 2016 travestido por uma embalagem midiática do "golpeachment" ". As forças que atuaram no golpe de 1964 ressurgiram com a diferença nas iniciativas políticas setoriais. Se em 1964 os militares assumiram a postura do velho ranço golpista com tanques e baionetas, agora cederam lugar para um perigoso protagonismo dos atores jurídicos em concomitância com o legislativo e a ala conspiratória golpista dentro do poder executivo.

O "fora todos", bordão comum nos protestos de época, se se metamorfoseou no "fora PT", bandeira "apolítica" dos protestos políticos na pretensa falsa retórica de repúdio da "política" (no caso, a política praticada pelos governos petistas no plano federal). A "negação da política" sempre foi uma estratégia tática dos grupos mais reacionários em busca de consolidar na grande massa a sua ideologia política e se tornou peculiar nos movimentos fascistas do século XX.

\footnotetext{
${ }^{2}$ O chamado Movimento Passe Livre (MPL), majoritariamente composto por estudantes secundaristas e universitários, se destacou no cenário nacional do segundo trimestre de 2013 com a demanda de fazer protestos em favor da "tarifa zero" para os transportes públicos da cidade de São Paulo. Na ocasião, um aumento da tarifa de ônibus, metrô e trens metropolitanos em 20 centavos desencadeou a primeira onda de protestos contra um governo do PT, cuja prefeitura estava sendo administrada pelo prefeito petista Fernando Haddad. Curiosamente, o aumento foi em conjunto dos governos estadual, administrada pelo tucano Geraldo Alckmin, e prefeitura, de Haddad, todavia o alvo principal do MPL foi voltado para a figura do prefeito petista.

${ }^{3}$ Há uma diferença substancial entre a interrupção do mandato do ex-presidente Fernando Collor, em 1992, e agora da ex-presidenta Dilma, em 2016 (LATTAMAN-WELTMAN, 2009). A história da república brasileira conviveu com poucos anos seguidos de ares de democracia política, fato este que foge do intuito de análise do presente trabalho.
} 
A força de imposição de ideias e administração de mundo está atrelada ao desejo das classes dominantes de manter sempre em seu controle os destinos da sociedade, conforme destaca Marilena Chauí:

[...] visto que as ideias dominantes de uma época são as ideias da classe dominante dessa época, o ponto de chegada da ideologia está necessariamente inscrito no seu ponto de partida, isto é, em ambos encontra-se o dominante revestido com a generalidade e a universalidade das ideias, que anulam e ocultam a realidade do dominante como uma classe particular (CHAUÍ, 2013, p. 129).

No momento atual, conforme preconizava Menezes (2014), a Caixa de Pandora se abriu e toda a direita e extrema-direita, que estavam hesitantes em mostrar explicitamente sua insatisfação seletiva contra os governos de Luiz Inácio Lula da Silva, histórico dirigente maior do PT, e Dilma Rousseff, foram para as ruas em rastro de indignação exclusivamente antipetista resultante de ação direta da grande mídia do país. Ao mesmo tempo, os partidos políticos de esquerda, sindicatos e movimentos sociais organizados, outrora letárgicos durante os anos petistas devido ao apoio dado aos governos Lula e Dilma, caracterizaram-se quase todos por uma "acomodação"; ficaram atônitos, acuados e espremidos nas cordas do ringue político-ideológico. É possível dizer que tais elementos que outrora sustentavam os governos petistas foram surpreendidos com o novo levante da "direita"4 (aqui representada pelo conjunto formado pelas diferentes forças conservadoras na sociedade), somente comparável às mobilizações que deram vazão à derrubada do governo de João Goulart (19611964) e culminariam no golpe civil-militar de 1964, resultando em mais uma longa interrupção da fragmentada democracia brasileira.

Mesmo após a reeleição de Dilma Rousseff em 2014, com 54.501.118 votos (51,64\% dos votos válidos), o seu governo já nasceu boicotado pelo grupo que saiu derrotado das eleições, encabeçado pelo Partido da Social Democracia Brasileira (PSDB), do senador por Minas Gerais, o fisiológico e cacique tucano, Aécio Neves, e por todo o império midiático das grandes corporações brasileiras de comunicação. A vida de Dilma seria piorada com uma das mais reacionárias composições de parlamentares do Congresso Nacional, cujo

\footnotetext{
"A respeito do "mapeamento de campo", considera-se, neste trabalho, a vitalidade dos esquemas de contrastes ideológicos caracterizados pelo par assimétrico "esquerda-direita". Alguns autores pós-modernos de corte neoliberal insistem em descaracterizar esta fundamental ambivalência de distinção política buscando menosprezar ou eliminar a forte carga ideológica nele impregnada. Ao negar a ideologia presente nas acepções dos posicionamentos políticos, cria-se uma nova ideologia "asséptica", onde o campo da política possa ser manifestado apenas por uma suposta "neutralidade" que, na prática, se mostra falsa e reducionista. Certamente, as concepções ideológicas na política merecem um estudo mais aprofundado, mas que escapa da proposta e dos limites deste presente trabalho.
} 
simbolismo se expressa em uma das bancadas mais reacionárias, a chamada "BBB" (letras iniciais do "boi" ligado ao "agrobusiness", da "bala" pertencente às facções de policiais com ares truculentos e, a mais conservadora de todas, a da "bíblia", a maior e ligada à crescente ampliação dos tentáculos das igrejas neopentecostais na política nacional).

Com a evolução das dificuldades da economia e erros crassos do segundo mandato de Dilma (MORTARI, 2016), os setores mais conservadores conseguiram paulatinamente uma forte aliança que incluiu os parlamentares dos partidos de oposição ao governo, cuja liderança ficou delimitada inicialmente ao PSDB e à sua linha-auxiliar, os Democratas (DEM, partido outrora se denominava Partido da Frente Liberal - PFL - e ex-ARENA. Este último formou a base congressista da junta militar que conduziu a ditadura militar no país entre 1964 a 1985). Todos esses partidos foram derrotados no pleito de 2015 e incluindo até mesmo partidos de apoio de Dilma, em particular, o Partido do Movimento Democrático Brasileiro (PMDB). Juntaram-se a esses partidos, setores de alto escalão do sistema judiciário e setores da macroeconomia lideradas pela Federação das Indústrias do Estado de São Paulo (FIESP) ${ }^{5}$. Conforme Edward Luttwak registrou em seu "manual" a respeito do golpe de estado:

Todo o poder, toda a participação estão nas mãos de uma pequena elite instruída. Essa elite é alfabetizada, educada, bem alimentada e segura, diferindo, portanto, radicalmente da ampla maioria dos outros cidadãos, praticamente uma raça diversa. As massas reconhecem isso e também aceitam o monopólio de poder da elite, e a não ser que algum abuso intolerável acarrete uma revolta desesperada, elas aceitarão suas políticas. Também aceitarão uma mudança no governo, seja pelos meios legais ou não. No fim das contas, trata-se apenas de outro grupo de "eles" tomando o poder. (LUTTWAK, 1991, p. 37)

É pertinente destacar que diante do "adestramento" da opinião pública visando fornecer o fomento ideológico, foi fundamental a adesão das grandes empresas midiáticas do país, lideradas pelos grupos Globo, Abril, Folha de S. Paulo e Estado de São Paulo, criando um discurso densamente seletivo, com técnicas similares às utilizadas pelo aparelhamento ideológico nazista, patrocinado por Joseph Goebbels, ministro da propaganda de Adolf Hitler (WYKES, 1975). A “narrativa do impeachment" foi alicerçada por uma grande frente

\footnotetext{
${ }^{5}$ Ficou muito conhecido o "ícone" produzido pela FIESP de um imenso pato amarelo de borracha exposto na fachada da sede da entidade no prédio da Avenida Paulista, o "coração financeiro" da cidade de São Paulo. A ideia dos seus idealizadores era chamar a atenção do oportunismo para atacar o governo da presidenta Dilma destacando a alardeada alta carga tributária no país. O bordão "Eu não vou pagar o pato", referência a respeito da carga de impostos que incide os mais diversos produtos comercializáveis, ficou muito impregnado nos protestos anti-PT e anti-Dilma.
} 
ideológica proveniente da grande burguesia brasileira $^{6}$, em particular, a paulista, liderada pela FIESP, patrocinando todo o aparato da "máquina midiática", que abusou das citadas técnicas de propaganda fascista. Neste delicado campo de operações psíquicas, a investida das táticas dos atos pró-impeachment foi explorar elementos inconscientes do sujeito/cidadão, buscando a desorganização social via apelo à neurose de grupo, tais como a desinformação, a seletividade, a massificação projetiva e a exploração do medo (SCHNEIDER, 1977; FREUD, 1996; ADORNO, 2015).

Nesta "onda conservadora" destaca-se a profusão ideológica que grassava na sociedade buscando negar, neutralizar ou deturpar a História, ou, como prescreve CHAUÍ (2013, p.131), “opera no sentido de impedir a percepção da historicidade”. Os ataques diários ao governo de Dilma se intensificavam de forma massiva, atingindo diretamente a sua figura pessoal, do ex-presidente Lula e do partido de ambos, o PT. A construção do imaginário de pureza entre "eu" e os "outros", ou da forma esplanada por Carl Schmitt, com a dicotomia amigo/inimigo, conduz para a criação de algo que seja a contraparte narcísica da investida libidinal do sujeito/cidadão, o "inimigo idealizado". Conforme preconizaram as lições de Schmitt em seu livro "O conceito de político", datado de 1932:

Os conceitos de amigo e inimigo devem ser tomados em seu sentido concreto e existencial, e não como metáforas ou símbolos, não misturados ou enfraquecidos por noções econômicas, morais e outras, e menos ainda em um sentido privadoindividualista e psicologicamente como expressão de sentimentos e tendências privadas. (SCHMITT, 2008, p. 29)

Ademais, sobre a massiva propaganda midiática e o comportamento social de viés fascista referente ao sujeito e às massas, é importante destacar:

O ganho narcísico fornecido pela propaganda fascista é óbvio. Ela sugere continuamente, e algumas vezes de forma maliciosa, que o seguidor, simplesmente por pertencer ao in-group, é o melhor, superior e mais puro que aqueles que são excluídos. Ao mesmo tempo, qualquer tipo de crítica ou autoconsciência é ressentido como uma perda narcísica e incita fúria. Isso explica a violenta reação de todos os fascistas contra o que eles julgam zersetzend [destrutivo], aqui que desmascara seus valores mantidos obstinadamente, e// também explica a hostilidade de pessoas preconceituosas contra qualquer tipo de introspecção. (ADORNO, 2015, p. 177, grifos do autor)

\footnotetext{
${ }^{6}$ Há fortes indícios de participação de fontes estrangeiras, notadamente estadunidenses, travestidas de beneméritas fundações que deram fomentos ideológicos e financeiros a alguns grupos de direita e extrema direita no país para organizarem movimentos em prol do impeachment de Dilma e campanha contra lideranças do PT, enfaticamente, Lula (MARIN, 2016).
} 
O mote da "corrupção" foi o carro-chefe de identificação negativa projetada exaustivamente pelos meios de comunicação. À alegoria do discurso midiático, somente os membros do PT eram diretamente envolvidos em corrupção, e a Operação Lava-Jato, que será vista a seguir, era uma espécie de ornamento sagrado para atirar os petistas na fogueira da inquisição midiática (lembrando que nomes de outros partidos eram sempre relativizados ou simplesmente negados, como o primeiro articulador do golpe de estado, o PSDB).

O clima de perseguição antipetista e o suposto "caos econômico" como herança do governo Dilma também foram citados à exaustão, principalmente para justificar todas as medidas socialmente nefastas pelo novo governo que assumiu após a derrubada de Dilma do poder e justificação de erguimento da economia abalada pela crise política. Sintomaticamente, os anos 2013 e 2014, anos dos protestos iniciais contra o governo Dilma, tiveram taxas anuais do nível de desemprego de 5,4\% e 4,8\%, respectivamente, ou seja, os menores índices já registrados no país (MARTINS, 2014; PELAJO, 2015). Sob o ponto de vista da disponibilidade de empregos, parece pouco plausível uma insatisfação "genuína" tão histriônica e voluntária da população justamente no período de menores taxas de desemprego da história recente do país. A evocação do endosso das massas para ganhar dividendos políticos imediatistas é uma prática corriqueira dos ocupantes do poder ou postulante a ele, conforme salienta Luttwak (1991, p. 36): “a massa é politicamente passiva, mas é a passividade do silêncio forçado, não da inércia. A terrível ira causada pelas privações e pela injustiça está sempre presente, e às vezes explode. A massa talvez não tenha um propósito claro, mas suas ações têm consequências políticas".

Como vice-presidente do governo Dilma, portanto, visceralmente atrelado à sua gestão, Michel Temer assumiu com uma cartilha completamente desproporcional e desconexa do plano de governo da antecessora, o mesmo que endossara e participara. As mais espetaculares e nitidamente desastrosas medidas foram anunciadas, desde a mudança radical da Previdência Social, Reforma Trabalhista (ou seja, na prática, seria o sepultamento das leis que protegeriam os direitos dos trabalhadores, a CLT, Consolidação das Leis do Trabalho), a privatização de empresas estatais e das reservas de petróleo a serem exploradas e a questão do pré-sal (BRAGON, 2016).

O governo Temer, à revelia das necessidades reais da maioria da população, que carece do Estado para promover políticas de bem-estar social, impôs cortes substanciais e congelamento de investimentos por décadas em áreas sociais, desmonte das leis trabalhistas e até mesmo alterações substanciais, por decreto, do currículo do Ensino Médio. Nenhuma dessas propostas foi debatida pela sociedade e sequer a nova junta governante passou pelo 
crivo do voto popular. Sob a construção de um estado de exceção, o soberano impõe as regras as quais serão obedecidas pelo bem do Estado e não do cidadão. Portanto, segundo Luttwak (1991), é da natureza daqueles que praticam o golpe buscar calar os descontentes a fim de buscar a legitimidade dos seus atos por meio da naturalização dos seus feitos, uma vez que "se o governo pré-golpe for produto de uma tomada de poder, os objetivos do golpe podem ser apresentados puramente em termos de restaurar a 'vida política normal' ou, se formos esquerdistas outrés, podemos falar da "necessidade de restaurar a democracia"' (LUTTWAK, 1991, p. 84, grifo do autor).

O paradigma da violência institucional ficou presente nas agressivas investidas da polícia militar contra grupos descontentes com o governo, os chamados "Fora Temer", particularmente em São Paulo, onde foram duramente reprimidos deixando diversos feridos em clima de pura brutalidade explícita do monopólio da violência estatal contra os descontentes no novo regime nas ruas (GARCIA, 2016). A baixa popularidade de Temer não significa necessariamente a recusa ao seu governo conclamado de "união nacional". O clima de buscar naturalizar as terríveis medidas impopulares levou até mesmo o governo a criar uma perdulária campanha provocativa e depreciativa, cujo slogan foi "Vamos tirar o Brasil do vermelho", com clara alusão à cor utilizada pelo partido da presidenta deposta e, ao mesmo tempo, se referir à "herança maldita" do governo Dilma no qual, curiosamente, o próprio Temer participou desde o primeiro mandato dela na condição de vice-presidente. A declaração de guerra ideológica apenas acirrará os ânimos políticos sem nenhum resultado concreto perante a mediação dos reais problemas do país (CARTA CAPITAL, 2016).

A representação da sociedade no campo da ideologia oferece certa racionalidade objetiva, à qual impõe o descarte da reflexão e do aprofundamento de "verdades inquestionáveis". Naquele momento, no furor dos acontecimentos alimentados pela "política de ódio" da grande mídia desejosa pela queda do PT e de Dilma, alicerçou a narrativa catastrófica ao estilo sensacionalista, de que tudo de pior no país teria duas letras: "PT". O "apagamento da História" se fez presente na ideologia que dominou o cenário "préimpeachment": uma saraivada de informações jorradas incessantemente por toda a mídia impressa, radiofônica, televisiva e eletrônica a respeito dos supostos "crimes" da "quadrilha do PT". Como se o país tivesse sido "inaugurado" no dia da posse do primeiro mandato do ex-presidente Lula e se tornado tão degenerado no final do governo Dilma a ponto de necessitar jogar tudo na fogueira da "Santa Inquisição" midiática e "refundar" o "meu país", 
como milhares de manifestantes exaltavam em praças públicas aos protestos contra Dilma e ao uso generalizado da camiseta amarela da Confederação Brasileira de Futebol (CBF).

Como sintoma de um momento peculiar da fragilidade ideológica dos "indignados" exclusivamente contra o PT e o governo Dilma, o uso de camisetas da seleção de futebol nacional recorre à manifestação de um suposto patriotismo pontual, beirando uma espécie de ufanismo com viés fascista, uma vez que na ausência de uma consistência mais estrutural do desejo manifesto por via de uma consciência de classe, o sujeito agarra-se a qualquer coisa que possa exprimir uma voz à "pulsão de morte" que movimentou protestos ancorados pela imposição coercitiva do aparelhamento ideológico da grande mídia, em particular, a Rede Globo.

Sobre a construção histórica das narrativas dos fatos, são válidas as percepções pertinentes de Chauí (2013) sobre a história escrita pelas classes dominantes e, aqui no caso específico, temos a narrativa constituída para a justificação da derrubada de Dilma, em que substituíram os historiadores pela narrativa pró-impeachment dos meios de comunicação:

A ideologia fabrica histórias imaginárias legitimadoras da dominação da classe dominante e, por isso, [...] sempre são narradas do ponto de vista do vencedor, de maneira que não há registro das ações dos vencidos e delas não restam vestígios na memória social. Por isso, os dominados aparecem nos textos dos historiadores sempre a partir do modo como eram vistos e compreendidos pelos próprios vencedores postos como sujeito único da história. (CHAUÍ, 2013, p, 140)

Ademais, a pequena-burguesia que saiu às ruas tinha um desejo por um aburguesamento de sua condição social e era temerosa quanto à sua possibilidade de proletarização (CHAUÍ, 2013). Aderir ao "ódio anti-PT" era muito mais confortável do que adentrar numa batalha mais crível contra o seu espelho narcísico que era a própria (e de fato) burguesia.

\section{Sintoma da Justiça partidária: O fator "Lava-Jato" e "tempos excepcionais" da sociedade brasileira}

Desde abril de 2014, com a supervisão do Procurador-geral da República, Rodrigo Janot, uma força-tarefa do Ministério Público Federal que ficou conhecida como "Operação Lava Jato", sediada no estado do Paraná, transformou uma investigação de desvio de dinheiro da Petrobras na maior operação midiática para influenciar diretamente os resultados políticos da história brasileira recente. Com um grupo de procuradores com grande apelo aos holofotes 
televisivos e tendo o juiz de primeira instância, Sérgio Moro, como protagonista de uma longa "novela judiciária", os resultados políticos culminaram na narrativa de criminalização do PT, sendo, diariamente elaborada pelos meios de comunicação de forma seletiva e passional para influir decisivamente na opinião pública. Conforme o próprio juiz Moro em uma das suas inúmeras aparições da imprensa deixou "escapar" o fio condutor de suas ações "excepcionais":

\begin{abstract}
"Claro que a prisão preventiva é excepcional, mas, infelizmente, estamos em tempos excepcionais", justificou. "Mas mesmo essa excepcionalidade tem sido citada, nos casos que a comporta, dentro dos marcos legais. De maneira nenhuma eu [Sérgio Moro] defendo qualquer excepcionalidade em relação à inobservância da lei", afirmou. (AZEVEDO, 2016)
\end{abstract}

Vale lembrar a controversa e abusiva opereta sensacionalista da chamada "delação premiada" ou, da maneira formal, "colaboração premiada" (BRASIL, 2013), na qual um suposto acusado "dedura" quem ele desejar em troca de benesses futuras da pena. Esses expedientes fizeram a farra novelística da grande imprensa: acusados da Lava Jato denunciavam sem provas e pessoas foram expostas em cadeia nacional como "grandes ladrões" da sociedade, enfatizando sempre a alcunha pejorativa de "amigos de Lula". O estado democrático de direito que salvaguardava a presunção de inocência foi substituído por um estado de delação, histeria puritana e pré-julgamentos sem provas e sequer elementos acusatórios com alguma solidez processual (AZENHA, 2016; CAGNI, 2016; AGUIAR; ARAÚJO, 2015).

Municiados ideologicamente pelo ativismo jurídico anticonstitucional e partidarizado, grupos que se orgulhavam em autodenominar-se "apolíticos" doutrinados por uma ideologia neoliberal", como o "Movimento Brasil Livre" (MBL) e o "Vem Pra Rua", com apoio maciço

\footnotetext{
${ }^{7}$ Por detrás do discurso "apolítico", tais grupos foram criados, orquestrados e financiados por ONGs estrangeiras e partidos políticos de oposição ao governo (em particular, PSDB, DEM e setores do PMDB). Seus membros com discursos profundamente reacionários participaram ativamente como candidatos das eleições municipais de outubro de 2016, o que fez cair por terra todo falso elã "apartidário" que ostentavam nas redes sociais e nas ruas. O exemplo do "sucesso" eleitoral da onda "anti-PT" foi a eleição do líder do MBL, Fernando Holiday pelo DEM, para ocupar uma cadeira na Câmara dos Vereadores da cidade de São Paulo. Holiday, um controverso jovem negro e homossexual que fez discursos agressivos justamente contra os grupos sociais o qual fisicamente ele pertencia, ficou conhecido pela atuação midiática contra o PT atrelado a uma retórica de ódio e incisivo discurso neoliberal. Neste cenário, Holiday estava surfando na nova onda da extrema-direita que ressurgiu após 2013 no Brasil e, por sua vez, refletia o turvo cenário ideológico das direitas extremistas estadunidenses e europeias. Ademais, é necessário salientar, foi uma emblemática captura do discurso culturalista (originário de uma penetração do discurso pós-moderno dentro dos partidos de esquerda) pelo jovem Holiday, o que expôs, mais uma vez, a fragilidade e porosidade das bandeiras identitária que são absorvidas demagogicamente pelos partidos de direita em um cenário de intensa disputa política e dominada pelos setores mais reacionários da sociedade. Tal discussão é altamente pertinente para a reflexão crítica dos partidos de esquerda do pós-Muro de Berlim, mas foge do escopo do presente trabalho.
} 
dos meios de comunicação, levaram milhares de pessoas, em particular, da classe média, para as ruas contra o governo de Dilma Rousseff e o PT. Ações que formaram um esdrúxulo espetáculo promovido pela direita brasileira, ou seja, os setores mais conservadores e reacionários, manifestada nas "marchas do ódio", após 2013, foram um show de condução de grupos sociais supostamente "enfurecidos" pelos parcos progressos sociais das classes mais baixas promovidas pelos governos Lula e Dilma ${ }^{8}$. Nada se apresentou mais "inaceitável” para certa parcela reacionária e articulada da classe média do que a "ascensão dos debaixo", ou seja, o que estava em jogo era a disputa de espaço dentro da sociedade de um grupo de privilegiados contra aqueles que poderiam macular tais privilégios. Nas redes sociais, o clima de hostilidade e ódio dava uma dimensão do quão parcial, distorcida e empobrecida estava aos olhares dos "internautas" que eram incessantemente bombardeados por notícias negativas do governo Dilma, da ação persecutória da vida pessoal do ex-presidente Lula e das ações do PT. Canalizando para o apelo a uma "neurose de massa", todo um afeto de ódio estimulado diariamente pelos meios de comunicação foi sedimentado em uma espécie de "tripé de Geni""9: Dilma, Lula e o PT.

As tensões políticas se aprofundavam e os padrões de acirramento se acentuavam, criando um imaginário social de desapreço à democracia, aos partidos políticos e à própria política. As artificiais e superficiais coalizões políticas suprapartidárias com interesses meramente mercantis de poder e verbas públicas que vigoravam em toda a Nova República, perfazendo todas as gestões dos presidentes, chegavam a um limite no segundo governo Dilma (2015-2016). À medida que a onda de denúncias atingia diretamente o PT com a repercussão da dramaturgia oriunda das investigações da Operação Lava Jato, a base de sustentação do governo Dilma se fazia cada vez mais porosa. Como critica Vera-Cruz Pinto (2015, p.11, grifos do autor) a sujeição de um abusivo protagonista de membros da justiça brasileira ao se aproximar do modelo estadunidense o qual “[...] o juiz assume um

\footnotetext{
${ }^{8}$ Como paralelo na História recente brasileira, em 1964, ficou conhecido a "Marcha pela Família com Deus e pela Liberdade" que aglutinou milhares de pessoas das classes média e alta, particularmente em São Paulo, em reação a uma suposta "ameaça comunista" e contra o então governo do presidente João Goulart. No Rio de Janeiro, a edição da marcha ficou conhecida como a "Marcha da Vitória". Ambas as marchas tiveram amplo apoio dos grandes meios de comunicação da época e foram encabeçadas por partidos políticos contrários ao governo de Goulart. Tal como em 2016, as marchas de 1964 serviram para canalizar o momento de insatisfação de grupos setorizados da sociedade e criar uma farsesca imagem de respaldo com o "apoio popular" ao golpe civil-militar do período.

${ }^{9}$ Aqui, uma alusão à célebre canção de 1978 composta por Chico Buarque, "Geni e o Zepelim”. Na música de Chico, a personagem de Geni era uma figura transgressora e indesejada pelos habitantes locais, que após salvar sua cidade de um ataque de um zepelim, um balão dirigível de origem alemã, e o perigo se afastou para seus habitantes, volta a ser escorraçada pela sociedade demonstrando todo o caráter hipócrita e moralista da sociedade.
} 
protagonismo 'hollywoodesco', permitido pela norma constitucional e requerida pela sociedade do "star-system"”.

Com a evolução performática da Lava Jato, que acusava com provas frágeis nomes particularmente ligados ao PT, as ações seguiam tendo como estratégia tripla em "tempos excepcionais": o ataque ao governo Dilma, a desmoralização de Lula e a criminalização do PT. Neste anticlímax da governabilidade, o governo Dilma colocava em pauta um problemático programa de ajuste fiscal que culminaria com o viés de recessão econômica para os setores produtivos. O quadro internacional com preços do petróleo em queda culminaria na desestabilização do real frente ao dólar, com adicionais prejuízos contábeis para a Petrobras (incluindo toda a chamada "economia do petróleo" sofrendo o revés com a baixa dos preços no mercado internacional). Na miscelânea de fatores anti-Dilma, sua popularidade era medida por institutos de independência e isenção questionadas: IBOPE e DATAFOLHA, dois grupos que, ligados aos setores de comunicação mais interessados na queda do governo, faziam a "festa" dos números negativos.

Um fator decisivo para a queda do governo Dilma foi o protagonismo passional do Poder Judiciário na cena política. Não apenas o fator novelesco partidarizado da "Lava Jato" influiu nos ânimos da sociedade perante o governo, mas as sucessivas articulações do Supremo Tribunal Federal (STF), com seus membros protagonizando ações de total desrespeito constitucional, colaboraram para criar um clima de golpismo que poderia culminar no encerramento de mais um ciclo democrático no país (FELLIPE, 2016).

A avalanche midiática apenas ampliava-se em torno da construção alegórica na narrativa do "impeachment” da presidenta Dilma, ou seja, a articulação do golpe parlamentar, o "golpeachment" sobre uma oportunista acusação de "crime de responsabilidade" mediante “pedaladas fiscais". A Câmara dos Deputados, em 17 de maio, fez o mais tétrico espetáculo circense da sua história, comandado pelo então presidente da Casa, Eduardo Cunha ${ }^{10}$ que, posteriormente teve o seu mandato de deputado federal cassado por denúncias de corrupção. De uma forma tão surreal, após a votação derradeira do impeachment de Dilma no Senado no

\footnotetext{
${ }^{10}$ Eduardo Cunha, um dos mais corruptos e fisiológicos políticos do PMDB, foi um agente central do tear conspiratório que envolveu a queda de Dilma, uma vez que conseguiu se articular para ocupar o posto de Presidente da Câmara dos Deputados, sendo que usou o cargo para proveito pessoal e para dirigir todo o certame político que decorreu até a votação final da cassação de mandato de Dilma. Quando no auge do furor anti-PT, Cunha foi aclamado "herói nacional" pelas protestantes da direita e tido como um exemplo da "luta contra a corrupção do PT". Ademais, é preciso esclarecer ainda muitos fatos nebulosos destes episódios tendo Cunha como um articulador central do golpe e hoje, no atual momento, é mantido na cadeia por seus crimes de corrupção (ou, como é possível também olhar sob outro prisma, é mantido em "silêncio" tendo em vista um golpe de estado em curso).
} 
dia 31 de agosto, dois dias depois, a Câmara dos Deputados aprova medida em que as manobras fiscais da "pedalada" seriam válidas para o governo Temer!

Para obter êxito, um golpe de estado carece de uma maquinaria refinada entre seus elementos insurgentes que possam aglutinar entusiastas, alavancar condições materiais e ideológicas e sustentar na prática tal evento de "engenharia política". No caso do golpe de 2016, foi arregimentada uma articulação que envolveu amplo segmento da burguesia nacional, envolvendo os setores parlamentares, grande mídia, empresários ligados à FIESP, sistema financeiro e setores da classe média de maior poder aquisitivo (neste grupo, entram também os funcionários públicos do Poder Judiciário com altos salários). Essa amálgama política densamente difundiu seus ideários em todos meios de comunicação, conduzindo o país a um caldo de cultura golpista similar aos movimentos pré-1964, a antessala do golpe militar. O resultado tragicamente se repetiria com requintes mais sórdidos e agora transformado em "golpe parlamentar" no fatídico dia 31 de agosto, com o tiro de misericórdia dado pelo Senado Federal, com toda anuência e participação do STF, o fiador jurídico do golpe: Dilma é deposta, e seu vice, Michel Temer, líder do PMDB, assume o poder, traindo sua ex-companheira de chapa em um dos episódios mais escatológicos da política nacional.

Sobre o exibicionismo midiático da justiça brasileira, são sintomáticas as chamadas "dez medidas de combate à corrupção", que o Ministério Público Federal (MPF) vem divulgando como uma grande panaceia para "acabar com a corrupção brasileira”, de forma sensacionalista perante a opinião pública. Segundo o próprio site do MINISTÉRIO PÚBLICO FEDERAL (2016), o MPF vem encabeçando, junto à sociedade no afã de obter o apoio populista da população, uma série de violações à Constituição Federal de 1988 e criando um amplo e perigoso caminho para as práticas persecutórias típicas de regimes fascistas, a diluição do sentido jurídico do "Habeas Corpus", a legalização da política indiscriminada do encarceramento em massa, a diluição da presunção de inocência de qualquer cidadão ao inverter o ônus da prova e cria mecanismos surreais de prisão como a armação de "joguetes persecutórios" (os insanos e aviltantes "testes morais" para os servidores públicos, exceto para os membros do Judiciário, é claro!) conforme é tresloucadamente proposta na primeira das dez propostas feitas por alguns membros mais "politizados" do MPF" ${ }^{11}$. Curiosamente, quanto mais o MPF deseja avançar no "combate à

\footnotetext{
${ }^{11}$ O mais surreal ainda nesta "façanha" do MPF, uma entidade jurídica pública, é a divulgação, em site oficial na internet, de uma prosaica lista de "apoiadores" do arranjo populista partidarizado dos promotores públicos federais traduzidos nas "dez propostas contra a corrupção". Encabeça a lista dos "apoiadores" uma série de personalidades sem relevância alguma no âmbito jurídico, social, político ou acadêmico, tais como artistas Gloria Pires e Reynaldo Gianecchini, um apresentador de talk-show, Danilo Gentile, conhecido por suas
} 
corrupção" entre a classe política, paradoxalmente é no Poder Judiciário que se encontra um nível de corporativismo e impunidade que transforma operadores da lei, como juízes e promotores, em seres intocáveis no Brasil (ASSIS, 2016). O estado de exceção no Brasil se consolidaria assim com elementos que exterminariam o estado democrático de direito e todas as prerrogativas constitucionais de garantias à dignidade da pessoa (CONSTITUIÇÃO FEDERAL, 1988), em particular, o seu quinto artigo ${ }^{12}$.

O conjunto destas leis, que não passaram por nenhum crivo do debate na sociedade, é proposta exclusiva de um grupo de promotores federais que, na prática, querem fazer uma reforma a fórceps no Código de Processo Penal. Atualmente, tramita na Câmara dos Deputados Projeto de Lei 4850/2016, apresentado em 23 de março de 2016, surfando na crista da onda, a qual os promotores públicos federais investiam contra o PT, dando apoio “político-jurídico" para a derrubada do governo Dilma. Todos os deputados que assinam o PL, encabeçado pelo Deputado Antônio Carlos Mendes Thame (PV/SP), como Diego Garcia (PHS/PR), Fernando Francischini (SD/PR), João Campos (PRB/GO), foram favoráveis ao impeachment da ex-presidenta Dilma Rousseff e seus partidos, e atualmente integram a base de apoio ao novo governo que ocupou o poder, após o golpe parlamentar. Desta maneira, o que se conclui é que houve um elo (ou, no mínimo, a "colaboração") entre promotores públicos e parlamentares que efetivamente atuaram no golpe de estado para ampliar o clima anti-PT e anti-Dilma com supostos "desvios de conduta" por parte do governo deposto tendo como base o mito da "corrupção" como causa de todos os males da sociedade brasileira.

Sobre o êxito do atual golpe de estado no Brasil, é possível observar as pertinentes lições de Luttwak (1991) quanto às estratégias de colocar o povo (as massas) sob estado de inação:

[...] após um golpe, o policial da aldeia lê uma proclamação, o rádio diz que o antigo governo era corrupto e que o novo proporcionará comida, saúde e educação -

\footnotetext{
posições grotescas, fascistas e infantilizadas, a ex-modelo Luiza Brunet, a cantora Preta Gil e o porta-voz do "Jornal da Globo", o conservador Arnaldo Jabor. Uma tendenciosa lista de "subcelebridades" que, no mínimo, mereceria um prêmio para unir tantas personalidades sem nenhum compromisso com a Justiça e com as questões sociais! Como é possível que procuradores públicos, remunerados pelo erário e com responsabilidade jurídica sobre a sociedade, chegassem a tal ponto de tamanho populismo vazio e troglodita, em troca de narcisistas holofotes midiáticos? (MINISTÉRIO PÚBLICO FEDERAL, 2016).

12 Um exemplo da crescente ingerência abusiva do Poder Judiciário, frente aos direitos constitucionais e privacidade dos cidadãos, são os constantes bloqueios arbitrários do aplicativo de comunicação entre celulares chamado WhatsApp. A cada momento, inesperadamente, uma decisão judiciária pede suspensão do aplicativo sem justificativa alguma, apenas para criar um instantâneo protagonismo midiático do magistrado que a expediu de forma arbitrária, com repercussão para todo território nacional, atropelando toda a legislação sobre o chamado "Marco Civil da Internet" (INTERVOZES, 2016).
} 
e às vezes até mesmo glória. A maioria do povo não acreditará nem desacreditará dessas promessas ou acusações, sentindo apenas que tudo isso está acontecendo em algum lugar longínquo. Essa falta de reação é tudo o que o golpe necessita da parte do povo a fim de permanecer no poder. (Luttwak, 1991, p. 37-38)

$\mathrm{O}$ atual estado de exceção brasileiro se plasmou na mescla entre um poder executivo parido por um golpe de estado, um parlamento sem credibilidade política e com maioria de congressistas com denúncias na Justiça e um sistema judiciário que partidariza as questões jurídicas sem nenhum apreço à defesa institucional da Constituição vigente no país.

\section{Observações finais}

O Brasil adentrou na maior crise política do século XXI, sob o manto sinistro de mais um golpe de estado, sob a versão de um "golpeachment". A política de conciliação de classes construídas pelo PT desde o primeiro mandato e transcrita na famosa "Carta ao Povo Brasileiro" (FOLHA ONLINE, 2002), plataforma eleitoral de Lula em época de disputa eleitoral em junho de 2002 para "acalmar o mercado financeiro" e afagar a resistente e reacionária burguesia interna, apesar de ter seus momentos áureos com crescimento consistente do PIB e com a introdução de políticas sociais que retiraram parcialmente milhões de brasileiros da linha de pobreza, não existe mais, ruiu por completo!

Os falsos arranjos de interesses foram definitivamente rompidos e são nítidas as fraturas entre as classes sociais nos interstícios das disputas não declaradas e dos objetivos por detrás de um golpe. O estado democrático de direito vem se pulverizando avassaladoramente e, no seu lugar, crescem os tentáculos do estado de exceção, com suas doutrinas não-inscritas de coerção dos cidadãos diante da obsolescência da democracia como alternativa contra a barbárie.

Neste sentido, cabe recuperar o pensamento do polêmico pensador alemão, Carl Schmitt, não como paradigma a ser instaurado, mas, ao contrário, para buscar entender as tentações de suas lições que tanto agradam aos governantes dos Estados modernos. Diante da velocidade dos acontecimentos, em ritmos alucinantes, o cidadão da "pólis" (aqui na referência do "sujeito comum", quando há alguma participação dentro da sociedade) não consegue compreender, com um mínimo de clareza, o que se passa realmente ao seu redor (pode-se entender como uma decorrência angustiada das neuroses em grupo). A insistência das informações jorradas nos meios de comunicação a todo instante não visaram à reflexão do cidadão/espectador, mas à repetição automática até se cristalizar em uma suposta 
"verdade" (quase) absoluta. A pretensa "era da informação", que muitos entusiastas acreditavam como panaceia positivista de observação de mundo, apenas se consolidou em mais um mecanismo de manipulação de massa. Informação não é conhecimento, mas tem seus méritos de condução psicológica de grupos de interesses.

Nesta zona de anomia ou "espaço vazio", tal como foi chamado por Giorgio Agamben, onde as leis constitucionais são mantidas em suspensão, como um corpo enfermo e inerte ligado a tubos de oxigênio e alheio à vida real, o estado de exceção se fortalece e se faz presente sem praticamente nenhuma resistência na sociedade. Tal como foi dito, o estado exceção se apresenta como um patamar indeterminado, uma zona nebulosa, entre a democracia e o absolutismo.

Vale lembrar o que estado de exceção nunca saiu de cena no Brasil, mesmo com o fim oficial do golpe civil-militar em 1985, pois, dentro do modelo de modernização excludente, ele sempre existiu nos guetos, nas favelas e nas comunidades mais paupérrimas das cidades brasileiras. O estado democrático de direito nunca existiu nestas regiões, dominadas pela violência de diversos níveis, deixando uma população à margem de qualquer processo democrático e sem participação ativa nas decisões reais da vida pública em qualquer âmbito.

A crítica liberal, por sua vez, entoa o discurso de que a democracia é uma construção moral, na qual todos seriam culpados pelos acontecimentos políticos e generalizando as responsabilidades. Será que a grande burguesia nacional, que lucrou no tempo do Regime Militar e também no período da "redemocratização" e participou ativamente nos golpes de 1964 e 2016, está no mesmo patamar de responsabilidade de parcela significava de trabalhadores cuja vida sofrida transitou nos aglomerados infernais da precariedade do transporte público? As raízes autoritárias brasileiras vão além do simplismo moralista, quase beirando o senso comum, como, analisa Brum (2017). Os possíveis avanços para a solidificação de uma democracia oriunda de modelos estadunidense ou europeu dentro de um contexto de desenvolvimento brasileiro de capitalismo tardio passam por uma necessária responsabilização coletiva da sociedade. Todavia, não é possível creditar todas as mazelas autoritárias a sujeitos sociais diametralmente díspares em sua condição socioeconômica e atuação política. Quando se busca fazer um simplista e emotivo "exercício de socialização" das responsabilidades, retira-se, sem demora, o peso maior daqueles elementos que são responsáveis diretos pelos fatos, minimizando suas atuações fulcrais, e elevando a responsabilidade daqueles que são muito mais vítimas dos acontecimentos do que algozes deles. 
A chamada "Nova República" chegou ao seu fim de forma caduca e trágica. O novo golpe de estado brasileiro não irá abrir nenhum caminho para novos ares democráticos, ao contrário, as interrupções da democracia sempre deixam marcas traumáticas na sociedade e sempre impactando graves reveses no desenvolvimento socioeconômico. A falência do modelo político democrático de representação parlamentar, a negação da política pelos oportunistas que se servem dela, o espetáculo narcisista e obscuro da perversão às normas constitucionais para dar vazão ao protagonismo de elementos do judiciário partidarizando questões essencialmente políticas e o colapso do sentido da política são elementos altamente explosivos que abalam quaisquer estruturas democráticas. No caso brasileiro, a sociedade se aventura por caminhos já conhecidos, os quais não trouxeram nenhuma luz substancial para a vida social.

\section{Referências bibliográficas}

ADORNO, Theodor. W. Ensaios sobre psicologia social e psicanálise. São Paulo: Editora Unesp, 2015.

AGAMBEN, Giorgio. Estado de exceção. São Paulo: Boitempo, 2004.

AGUIAR, Gustavo; ARAÚJO, Carla. STF decide que polícia só pode invadir casas sem mandado em casos excepcionais. O Estado de S. Paulo, São Paulo, 05 nov. 2015. Disponível em: http://sao-paulo.estadao.com.br/noticias/geral,stf-decide-que-policia-so-pode-invadircasas-sem-mandados-em-casos-excepcionais, 1791643

ASSIS, Vinícius. Aposentadoria, com salário, até para magistrado que vendeu sentença. El País Brasil, São Paulo, 8 out. 2016. Disponível em: http://brasil.elpais.com/brasil/2016/10/07/politica/1475794566 642340.html Acesso: 08 out. 2016.

AZENHA, Manuela. Diretor de Direitos Humanos da OAB-SP: "Estamos numa antessala da ditadura?". Revista Brasileiros, 09 set. 2016. Disponível em: http://brasileiros.com.br/2016/09/diretor-de-direitos-humanos-da-oab-sp-estamos-numaantessala-da-ditadura/ Acesso: 09 set. 2016.

AZEVEDO, Guilherme. "Estamos em tempos excepcionais", diz Moro ao defender prisões preventivas. Folha de S. Paulo, São Paulo, 04 out. 2016. Disponível em: http://noticias.uol.com.br/politica/ultimas-noticias/2016/10/04/estamos-em-temposexcepcionais-diz-moro-ao-defender-prisoes-preventivas.htm Acesso: 04 out. 2016. 
BRAGON, Ranier. Câmara aprova fim da obrigatoriedade da Petrobras na exploração do présal. Folha de S. Paulo, São Paulo, 05 out. 2016. Disponível em: http://www1.folha.uol.com.br/mercado/2016/10/1820294-camara-aprova-fim-daobrigatoriedade-da-petrobras-na-exploracao-do-pre-sal.shtml Acesso: 05 out. 2016.

BRASIL. Constituição da República Federativa do Brasil. Brasília, 5 out. 1988. Disponível: http://www.planalto.gov.br/ccivil_03/constituicao/constituicaocompilado.htm Acesso: 01 ago. 2016.

BRASIL. Lei No 12.850, de 2 de agosto de 2013. Define organização criminosa e dispõe sobre a investigação criminal, os meios de obtenção da prova, infrações penais correlatas e o procedimento criminal; altera o Decreto-Lei no 2.848, de 7 de dezembro de 1940 (Código Penal); revoga a Lei no 9.034, de 3 de maio de 1995; e dá outras providências. Disponível em: http://www.planalto.gov.br/ccivil_03/_ato2011-2014/2013/lei/112850.htm Acesso: 10 ago. 2016.

BRUM, Eliane. A Lava Jato como purgação e maldição. El País, 26 jun. 2017. Disponível em: http://brasil.elpais.com/brasil/2017/06/26/opinion/1498488947_331660.htmlAcesso em 26 jun. 2017.

CARONE, Edgard. A Primeira República (1889-1930). Rio de Janeiro; São Paulo: Difel, 1976.

CARTA CAPITAL. Governo Temer lança campanha para "tirar o Brasil do vermelho". Carta Capital, São Paulo, 05 out. 2016. Disponível em: http://www.cartacapital.com.br/blogs/parlatorio/temer-comeca-campanha-para-tirar-o-brasildo-vermelhoAcesso: 06 out. 2016.

CAGNI, Patrícia. Maioria do STF mantém possibilidade de prisão após condenação em segunda instância. Congresso em Foco, 05 out. 2016. http://congressoemfoco.uol.com.br/noticias/maioria-do-stf-mantem-possibilidade-de-prisaoapos-condenacao-em-segunda-instancia/ Acesso: 05 out. 2016.

CÂMARA DOS DEPUTADOS. PL 4850/2016. Disponível em: http://www.camara.gov.br/proposicoesWeb/fichadetramitacao?idProposicao $=2080604$ Acesso: 01 set. 2016.

CHAUÍ, Marilena. Manifestações ideológicas do autoritarismo brasileiro. Belo Horizonte: Autêntica Editora; São Paulo: Editora Fundação Perseu Abramo, 2013.

FELIPPE, Marcio Sotelo. Moro está autorizado a descumprir a Constituição? Carta Maior, 30 set. 2016. Disponível em: http://www.cartacapital.com.br/politica/moro-esta-autorizado-adescumprir-a-constituicao Acesso: 30 set. 2016. 
FOLHA ONLINE. Leia íntegra da carta de Lula para acalmar o mercado financeiro. Folha de São Paulo, 24 jun 2002. Disponível em: http://www1.folha.uol.com.br/folha/brasil/ult96u33908.shtmlAcesso em: 02 out 2016.

FREITAS, Jânio de. 'Soluções inéditas' da Lava Jato têm um nome: Tribunal de Exceção.Folha de S. Paulo, São Paulo, 25 set. 2016. Disponível em: http://www1.folha.uol.com.br/colunas/janiodefreitas/2016/09/1816607-solucoes-ineditas-dalava-jato-tem-um-nome-tribunal-de-excecao.shtml Acesso: 25 set. 2016.

FREUD, Sigmund. Psicologia de grupo e análise do ego. In: Além do Princípio de prazer, psicologia de grupo e outros trabalhos (1920-1922). Edição standard brasileira das obras psicológicas completas de Sigmund Freud, v. XVIII. Rio de Janeiro: Imago,1996.

GARCIA, Janaina. OEA: PM facilita ou reprime protestos conforme a ideologia de manifestantes. Folha de S. Paulo, São Paulo, 05 out. 2016. Disponível em: http://noticias.uol.com.br/politica/ultimas-noticias/2016/10/05/oea-pm-facilita-ou-reprimeprotestos-conforme-a-ideologia-de-manifestantes.htm Acesso: 05 out. 2016.

INTERVOZES. WhatsApp e o olhar de exceção como regra do Estado brasileiro. Carta Capital, São Paulo, 07 out. 2016. Disponível em: http://www.cartacapital.com.br/blogs/intervozes/whatsapp-e-o-olhar-de-excecao-como-regrado-estado-brasileiro Acesso: 07 out. 2016.

KITCHEN, Martin. História da Alemanha moderna: de 1800 aos dias de hoje. São Paulo: Cultrix, 2013.

LATTMAN-WELTMAN, F. Como fazer um presidente. Revista de História da Biblioteca Nacional, ano 5, n. 50, p. 63-65. Rio de Janeiro, 2009.

LUTTWAK, Edward. Golpe de estado: um manual prático. Rio de Janeiro: Paz e Terra, 1991.

MARIN, Pedro. Golpe no Brasil: a conexão internacional. Outras Palavras, São Paulo 11 mai. 2016. Disponível em: http://outraspalavras.net/brasil/golpe-no-brasil-a-conexaointernacional/ Acesso: 15 mai. 2016.

MARTINS, Diogo. Taxa média de desemprego em 2013 é a menor da história. valor Econômico, 30 jan 2014. Disponível em: http://www.valor.com.br/brasil/3413340/taxamedia-de-desemprego-em-2013-e-menor-da-historiaAcesso em: 21 set 2016.

MATOS, Olgária. Modernidade: república em estado de exceção. Revista de História, São Paulo, n. 59, p. 46-53, set./nov., 2003.

MENEZES, Wellington Fontes. A Caixa de Pandora: algumas considerações sobre os protestos de inverno em São Paulo (2013). In: Revista Espaço Acadêmico, n. 167, ano XIV. 
Maringá, jul. 2014, pp. 67-81. Disponível em: http://www.periodicos.uem.br/ojs/index.php/EspacoAcademico/article/view/22391 Acesso: 01 ago. 2016.

MINISTÉRIO PÚBLICO FEDERAL. Conheça as medidas. Brasília, 2016. Disponível em: http://www.dezmedidas.mpf.mp.br/apresentacao/conheca-as-medidas Acesso: 20 set. 2016.

MORTARI, Marcos. "O governo discute o remédio para a crise errada", diz economista. InfoMoney. São Paulo, 04 out. 2016. Disponível em: http://www.infomoney.com.br/mercados/noticia/5608808/governo-discute-remedio-paracrise-errada-diz-economista Acesso: 04 out. 2016.

PELAJO, Cristina. Brasil encerra 2014 com a menor taxa de desemprego já registrada. Jornal da Globo, 29 jan 2016. Disponível em: http://g1.globo.com/jornal-daglobo/noticia/2015/01/brasil-encerra-2014-com-menor-taxa-de-desemprego-jaregistrada.html Acesso em: 21 set 2016.

PRITCHARD, R. John. O incêndio do Reichstag. Coleção História Ilustrada da 2a . Guerra Mundial. Rio de Janeiro: Editora Renes, 1976.

WYKES, Alan. Goebbels. Coleção História Ilustrada da 2a . Guerra Mundial. Rio de Janeiro: Editora Renes, 1976.

SERRANO, Pedro Estevan Alves Pinto. Autoritarismo e golpes na América Latina: breve ensaio sobre jurisdição e exceção. São Paulo: Alameda, 2016.

SCHMITT, Carl. O conceito de político/Teoria do Partisan. Belo Horizonte: Del Rey, 2008.

SCHNEIDER, Michael. Neurose e classes sociais: uma síntese freudiano-marxista. Rio de Janeiro: Zahar Editores, 1977.

VERA-CRUZ PINTO, Eduardo. Prefácio. In: SERRANO, Pedro Estevan Alves Pinto. Autoritarismo e golpes na América Latina: breve ensaio sobre jurisdição e exceção. São Paulo: Alameda, 2016. 